\title{
PENINGKATAN PARTISIPASI MASYARAKAT DALAM KEGIATAN DONOR DARAH DI PALANGKA RAYA
}

\author{
Teguh Pribadi ${ }^{1}$, Asro' Laelani Indrayanti ${ }^{2}$, dan Elyta Vivi Yanti ${ }^{3}$ \\ ${ }^{1}$ Program Studi Kehutanan, Fakultas Pertanian, Universitas PGRI Palangka Raya \\ ${ }^{2}$ Program Studi Agribisnis, Fakultas Pertanian, Universitas PGRI Palangka Raya \\ ${ }^{3}$ Program Studi Pendidikan Geografi, FKIP, Universitas PGRI Palangka Raya \\ Email: tgpribadi@gmail.com
}

\begin{abstract}
The purpose of the blood donation social devotion program were: 1) to assisted the Blood Donor Unit of The Indonesian Red Cross (UTD-PMI) increased blood reserves to fulfil the blood needs in Palangka Raya city, 2) to socialized blood donation activities on the Universitas PGRI Palangka Raya (UPP) for the communities in and around the campus. Blood donation social activities were attended by 99 participants from students of police school (SPN), students, UPP Lecturers, university student organisation board (BEM), student regiment (Menwa), and the general public. By sex participants of this activity were dominated by men (73 people) and the women (26 people). The amount of blood bags that can be collected during this activity were 69 blood bags. Blood donation activities that are attractively packaged, publicized, and involving organizations/institutions can increase the level of community participation.
\end{abstract}

Keywords: blood donor unit, blood donation, participation, social devotion, Universitas PGRI Palangka Raya

\section{PENDAHULUAN}

Darah adalah jaringan ikat yang berbentuk cairan yang terdiri dari empat komponen yaitu sel darah merah (eritrosit), sel darah putih (leukosit), sel darah pembeku atau keping darah (trombosit), dan cairan darah (plasma darah). Darah merupakan alat pengangkut utama di dalam tubuh. Darah terdapat dalam pembuluh darah yang berwarna merah (Syaifuddin, 1995 yang dikutip oleh Budiningsih, 2011). Darah berfungsi sebagai 1) media pengangkut nutrisi ke seluruh jaraingan tubuh; 2) eritrosit berperan dalam pengangkutan oksigen dari paru-paru ke jaringan dan mengantarkan karbondioksida dari jaringan kembali ke paru-paru; 3) melawan infeksi yang dilakukan oleh leukosit; 4) mengatur keseimbangan asam basa untuk menghindari kerusakan jaringan; 5) menyalurkan metabolisme dari jaringan ke alat-alat sekresi; 6) menjaga suhu tubuh; 7) pendistribusian air ke seluruh tubuh; dan 8) menyerapkan hormonhormon dan enzim-enzim ke seluruh tubuh (Irianto, 2004 yang dikutip oleh Budiningsih, 2011). 
Rata-rata volume darah manusia adalah 6-8 \% dari berat tubuh atau sekitar 5-6 liter yang didominasi oleh komponen plasma darah (55\%), dan eritrosit (45\%) (Irianto, 2004 yang dikutip oleh Budiningsih, 2011). Kekurangan jumlah darah di dalam tubuh akan berakibat pada kerusakan jaringan dan kegagalan fungsi organorgan vital yang dapat menyebabkan kematian. Kekurangan pasokan darah dalam tubuh dapat diatasi dengan penambahan volume darah dari luar berupa darah pendonor (Windarto, 2011). Namun demikain, darah bukan benda sintetis yang dapat direkayasa dan hanya diproduksi oleh manusia sehingga penambahan darah hanya dapat dilakukan dengan menambahan darah yang berasal dari manusia (Aziz, 2000 yang dikutip oleh Sari, 2010).

Transfusi darah adalah kegiatan medis memberikan darah kepada seorang penderita yang darahnya telah disediakan dalam kantong plastik. Transfusi darah merupakan tindakan yang dilakukan dengan tujuan untuk memungkinkan penggunaan darah bagi keperluan pengobatan dan pemuliahan kesehatan yang mencakup masalahmasalah pengadaan, pengolahan, dan penyampaian darah kepada pasien
(PMI, 2002 yang dikutip oleh Janice, 2009). Sedangkan, Donor darah adalah proses penyaluran darah atau produk berbasis darah dari satu orang ke sistem peredaran darah orang lain. Donor darah berhubungan dengan kondisi medis seperti kehilangan darah dalam jumlah besar yang disebabkan oleh trauma, operasi, syok, dan tidak berfungsinya organ pembentuk sel darah merah (Depkes RI, 2009 yang dikutip oleh Sari 2010).

Ketersedian darah di bank darah sangat penting bagi masyarat yang sedang sakit. Transfusi darah dibutuhkan oleh mereka yang mengalami kekurangan darah akibat kecelakaan dan dalam kondisi gawat darurat, pasien-pasien yang sedang melakukan operasi besar, seperti operasi: jantung, bedah perut, seksio, sesarea, leukimia, hemofilia dan thalassemia (Aziz, 2000 yang dikutip oleh Sari, 2010). Cadangan darah yang tersimpan pada bank darah idealnya adalah satu persen dari jumlah penduduk yang ada (Depkes RI, 2009 yang dikutip oleh Sari, 2010).

Seiring dengan pertambahan penduduk maka kebutuhan cadangan darah terus meningkat. Akan tetapi, ketimpangan antara jumlah pasokan 
dengan permintaan darah di beberapa Unit Transfusi Darah (UTD) sering terjadi sehingga menyebabkan kelangkaan darah di UTD. Kelangkaan darah di UTD umumnya disebabkan oleh minimnya jumlah pendonor darah sukarela yang rutin dan aktif melakukan kegiatan donor darah (Sari, 2010). Jumlah pendonor darah sukarela di Indonesia hanya enam pendonor tiap 1.000 penduduk. Jumlah ini lebih sedikit di bandingkan dengan Thailand (13 pendonor /1.000 orang), dan Malaysia (10 pendonor/1.000 orang). Sedangkan, pendonor darah sukarela di Singapura mencapai 24 pendonor/1.000 orang), bahkan Jepang angka jauh lebih tinggi yaitu 68 pendonor /1.000 orang). Padahal kebutuhan darah di setiap negara relatif sama (Aziz, 2000 yang dikutip oleh Budiningsih, 2011).

Kelangkaan jumlah pendonor darah sukarela antara lain disebabkan oleh kekurangsadaran akan arti penting donor darah bagi kemanusiaan yang diungkapan dalam bentuk perasaan takut dengan jarum, takut darah akan habis, kekhawatiran akan darah yang didonorkan akan diperjualbelikan oleh oknum petugas PMI (Depkes RI, 2009 yang dikutip oleh Sari, 2010); pemahaman yang rendah tentang transfusi darah dan minimnya jumlah UTD-PMI (Janice, 2009).

Berdasarkan hal tersebut di atas maka, maka kami mengadakan kegiatan sosial donor darah dalam rangka meningkatkan partispasi masyarakat untuk melakukan kegiatan donor darah dengan melibatkan UTD-PMI Kota Palangka Raya dan BEM Universitas PGRI Palangka Raya (UPP). Kegiatan bakti sosial donor darah ini bertujuan: 1) Membantu UTD-PMI Kota Palangka Raya untuk meningkatkan cadangan darah untuk memenuhi kebutuhan darah di Kota Palangka Raya; dan 2) melakukan sosialisasi kegiatan donor darah di kampus bagi masyarakat kampus dan di sekitar kampus.

\section{KHALAYAK SASARAN}

Sasaran kegiatan bakti sosial ini antara lain masyarakat kampus (dosen dan mahasiswa), masyarakat umum dengan sasaran utama adalah mereka yang belum pernah melaksanakan donor darah dan pendonor darah pasif.

\section{METODE PELAKSANAAN}

Waktu dan Tempat. Kegiatan bakti sosial donor darah ini dilaksanakan pada Hari Minggu, 20 Oktober 2013. Tempat kegiatan bakti 
sosial ini dilaksanakan di Kampus UPP, Jalan Hiu Putih-Tjilik Riwut km 7, Palangka Raya.

\section{Pelaksanaan}

Kegiatan.

Koordinasi antara Panitia, BEM UPP dan UTD-PMI Palangka Raya dilaksanakan dalam rangka persiapan. Persiapan yang dilakukan meliputi penyiapan kelengkapan dan tempat pelaksanaan donor darah. Peserta donor darah didata dan diberikan kupon door prize oleh panitia (Gambar 1). Selanjutkan dilakukan pemeriksanaan kesehatan dan kelayakan sebagai pendonor darah oleh Petugas PMI Palangka Raya (Gambar 2 \& 3). Peserta donor yang sehat dan layak untuk melakukan donor darah menunggu di ruangan untuk melakukan donor darah (Gambar 4). Selama menunggu pendonoran darah, peserta disajikan hiburan oleh panitia. Pembagian door prize dilakukan pada akhir kegiatan (Gambar 5).

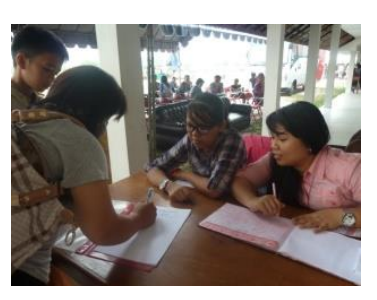

Gambar 1.

Pendaftaran peserta kegiatan bakti sosial donor darah.

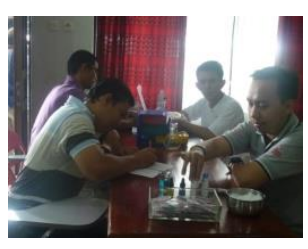

Gambar 2.

Pendataan calon peserta donor darah sukarela.

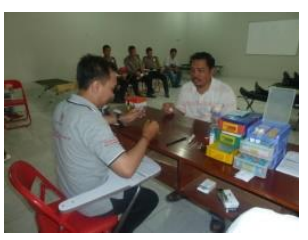

Gambar 3.

Pemeriksaan peserta donor darah sukarela.

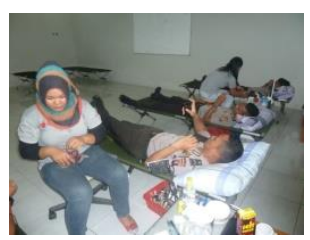

Gambar 4.

Pelaksanaan tindakan donor darah.

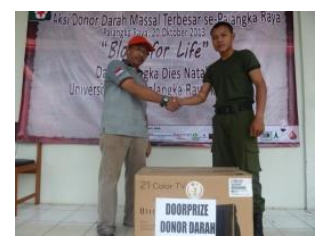

Gambar 5.

Pembagian door prize .

\section{HASIL DAN PEMBAHASAN}

Hasil. Kegiatan bakti sosial donor darah melibatkan dosen dan mahasiswa, UTD-PMI Kota Palangka Raya dan mitra kerja UPP yang telah membantu pendanaan dan publikasi kegiatan. Peserta kegiatan donor darah ini antara lain: siswa-siswa Sekolah Polisi Nasional (SPN) Palangka Raya, Anggota Brigade Mobil (Brimob), Anggota BEM UPP, anggota Resimen Mahasiswa (Menwa) UPP, mahasiswamahasiswa UPP dan Prodi Sosiologi 
Universitas Palangka Raya (UPR), dan masyarakat umum.

Total peserta kegiatan donor darah ini adalah 99 peserta. Peserta terbanyak berasal dari kelompok mahasiswa sebanyak 32 orang. Posisi kedua penyumbang peserta donor darah adalah siswa-siwa SPN Palangka Raya dengan jumlah 25 orang. Peserta berjenis kelamin laki-laki mendominasi jumlah peserta donor darah dalam kegiatan ini. Ada 73 orang laki-laki yang menjadi peserta donor darah dan sisanya adalah peserta berjenis kelamin perempuan (Tabel 1).

Tabel 1. Sebaran peserta kegiatan bakti sosial donor darah berdasarkan asal, jenis kelamin, dan tindakan donor darah.

\begin{tabular}{|c|c|c|c|c|c|}
\hline \multirow{2}{*}{ Asal peserta } & \multicolumn{2}{|c|}{ Jenis Kelamin } & \multirow{2}{*}{ Jumlah } & \multicolumn{2}{|c|}{ Donor darah } \\
\hline & Laki-laki & Perempuan & & $\mathrm{Ya}$ & Tidak \\
\hline Dosen & 3 & 3 & 6 & 4 & 2 \\
\hline Mahasiswa & 17 & 14 & 31 & 16 & 15 \\
\hline SPN & 25 & 0 & 25 & 23 & 2 \\
\hline Brimob & 4 & 0 & 4 & 4 & 0 \\
\hline Menwa UPP & 7 & 2 & 9 & 5 & 4 \\
\hline BEM UPP & 8 & 4 & 12 & 7 & 5 \\
\hline Masyarakat umum & 9 & 3 & 12 & 10 & 2 \\
\hline Jumlah & 73 & 26 & 99 & 69 & 30 \\
\hline
\end{tabular}

Pembahasan. Kegiatan bakti sosial donor darah ini berjalan dengan lancar dan sukses. Ukuran sukses kegiatan ini adalah jumlah peserta yang mencapai 99 orang dan jumlah kantong darah yang dikumpulkan mencapai 69
Jumlah kantong darah yang terkumpul dari kegiatan ini sebanyak 69 kantong darah. Kantong darah sebanyak 69 berasal dari 69 peserta yang telah memenuhi syarat-syarat sebagai pendonor darah. Pendonor darah terbanyak berasal dari siswa-siswa SPN diikuti oleh Mahasiswa, dan masyarakat umum yang berturut-turut sebanyak 23, 16, dan 10 orang (Tabel 1). Sebanyak 69 orang peserta yang mendonorkan darahnya, ternyata hanya 11 orang peserta berjenis kelamin perempuan yang bisa mendonorkan darahnya. 
dimungkinkan karena adanya pembagian door prize dari donatur untuk peserta donor darah yang beruntung. Selain itu juga adanya pemberitahuan di media cetak, pamflet dan undangan untuk lembaga dan organisasi yang berpotensi menjadi peserta donor darah sukarela. Publikasi kegiatan ini dibantu oleh anggotaanggota BEM UPP. Pemanfaatan media baik secara langsung ataupun tidak langsung untuk mengomunikasi kegiatan donor darah dapat meningkatkan pemahaman dan partisipasi masyarakat untuk melakukan kegiatan donor darah (Windarto, 2011).

Mahasiswa dan peserta didik SPN merupakan penyumbang terbesar peserta donor darah ini. Mereka melakukan kegiatan donor darah setelah mendapatkan instruksi atau arahan dari pemimpin mereka. Pendonor darah sukarela di Indonesia umumnya merupakan pendonor darah pasif yang melakukan donor darah setelah dimobilisasi oleh organisasi, lembaga, atau perkumpulam tempat mereka berafiliasi (Budiningsih, 2011). Sedangkan, masyarakat umum dan anggota Brimob yang ikut dalam kegiatan donor darah ini diperkirakan mereka adalah pendonor darah sukarela tetap dan ikut kegiatan ini setelah mendapatkan informasi dari media cetak dan pengumuman yang disampaikan oleh UTD-PMI Palangka Raya. Organisasi berperan penting dalam penyebaran informasi kegiatan donor darah (Sari, 2012).

Motivasi seseorang melakukan donor darah antara lain: iseng/mencoba, promosi kesehatan publik, keluarga/saudara membutuhkan transfusi darah, iba terhadap pasien yang memerlukan transfusi darah, diwajibkan oleh organisasi/instansi, untuk mendapatkan hasil pemeriksaan darah, dan mendapatkan penghargaan sosial (Janice, 2010). Motivasi mayoritas pendonor darah dalam kegiatan ini adalah kewajiban dan mencoba. Tindakan mencoba melakukan donor darah diawali dari kesadaran akan mendonorkan darah adalah suatu kebutuhan, setelah itu timbul ketertarikan, dilanjutkan dengan tindakan evaluasi untuk melakukan donor darah atau tidak. Tahap berikutnya adalah pengambilan keputusan untuk bertindak secara tepat. Selanjutnya ada adopsi yang mendorong seseorang berperilaku untuk mendonrokan darahnya berdasarkan pengetahuan, kesadaran, dan 
ketertarikan (Notoatmodjo, 2007 yang dikutip oleh Sari, 2012).

Faktor-faktor yang mempengaruhi seseorang melakukan donor darah umumnya dipengaruhi oleh faktor psikologi (pengetahuan dan sikap, kepercayaan) sosiodemografi (usia, berat badan, jenis kelamin, tingkat pendidikan, tingkat pendapatan, tingkat pengeluaran, daerah asal, pekerjaan, status), organisasi, serta faktor-faktor yang mempengaruhi kerelaan masyarakat melakukan donor darah sebagai upaya untuk memusatkan perhatian terhadap donor darah (Masser, 2008 yang dikutip oleh Sari, 2012); sosiobudaya: etnis dan agama (Sari, 2012).

Pendonor darah perempuan hanya sepertiga dari total jumlah pendonor darah laki-laki. Hal ini sesuai penelitian yang dilakukan oleh Jenice (2010) yang menyebutkan bahwa jumlah pendonor darah di Kota Medan dalam kurun waktu tiga tahun (2005-2007) didominasi oleh pendonor darah sukarela laki-laki dengan persentase mencapai $\quad>70 \%$ (Jenice, 2010). Perempuan umumnya memiliki stigma yang kurang baik terkait dengan jarum suntik ataupun darah di samping beberapa kondisi badan wanita yang menghalangi mereka untuk melakukan donor darah seperti haid, hamil, menyusui, dan kecenderungan gejala anemia, serta berat badan yang tidak memenuhi kriteria berdonor darah (Janice, 2010; Budiningsih, 2011).

Jumlah kantong darah yang terkumpul adalah 69 kantong darah, tidak semua peserta (99 orang) dapat mendonorkan darahnya. Hal ini terkait dengan kondisi kesehatan dan persyaratan teknis untuk melakukan donor darah. Syarat-syarat untuk melakukan donor darah: 1) umur antara 18-60 tahun (usia 17 tahun diperbolehkan menjadi donor darah setelah mendapatkan izin dari orang tua); 2) berat badan $\geq 50 \mathrm{Kg}$; 3) Suhu tubuh: $36,6-37,5{ }^{\circ} \mathrm{C}$; 4) tekanan darah 110-160 (sistole) dan 70-100 (distole); 5) denyut nadi teratur (70-95 kali/menit); 6) hemoglobin 12 gr/dl (perempuan) dan 12,5 gr/dl (laki-laki); 7) tidak sedang menderita penyakit jantung, hati, paru-paru, ginjal, diabetes, kanker, penyakit kulit kronis, dan tidak menderita penyakit infeksi: malaria, hepatitis, HIV/AIDS; 8) tidak menerima transfusi darah/komponen darah dalam enam bulan terakhir; 9) bagi pendonor darah tetap, donor darah terakhir adalah setelah $\geq 18$ minggu, maksimal donor 
lima kali dalam satu tahun; 10) tidak sedang hamil, menyusui dan menstruasi bagi wanita; 11) bukan pecandu alkohol/narkotika (UTD-PMI, 2010 yang dikutip oleh Budiningsih, 2011).

\section{SIMPULAN}

Kegiatan bakti sosial donor darah dilaksanakan diikuti oleh 99 orang peserta. Peserta kegiatan ini berasal dari mahasiswa (31 orang), siswa-siswa SPN (25 orang), Anggota BEM UPP (12 orang), masyarakat umum (12 orang), anggota menwa (9 orang), dosen UPP (6 orang), dan anggota brimob (4 orang). Jumlah kantong darah yang dapat dikumpulkan selama kegiatan ini sebanyak 69 yang diperoleh dari peserta donor darah yang telah memenuhi syarat-syarat teknis untuk melakukan donor darah. Partisipasi masyarakat kampus dalam kegiatan donor darah relatif baik. Lebih dari separuh peserta kegiatan ini berasal dari kalangan kampus, baik mahasiswa maupun dosen. Akan tetapi persentase keberhasilan tindakan donor darah (jumlah kantong darah yang terkumpul) dari masyarakat kampus lebih rendah dibandingkan dengan kalangan tertentu (Siswa-siswa SPN dan Brimob). Hal ini disebabkan oleh kondisi fisik dan kesehatan peserta donor darah dari kalangan kampus kurang memenuhi syarat-syarat teknis melakukan tindakan donor darah.

\section{SARAN}

Kegiatan bakti sosial donor darah yang diadakan di kampus UPP harus dilakukan secara berkesinambungan, diagendakan secara rutin, dan melibatkan masyarakat kampus yang lebih luas (diadakan pada hari kerja). Dukungan dan partisipasi unsur pimpinan di lingkungan UPP dapat meningkatkan tingkat masyarakat kampus. Selain itu, pengemasan kegiatan bakti sosial yang lebih menarik (hiburan dan pembagian door prize yang berasal dari pihak luar sebagai sponsor dan penyandang dana) juga dapat meningkatkan animo dan motivasi masyarakat untuk melakukan tindakan donor darah.

\section{UCAPAN TERIMA KASIH}

Ucapan terima kasih disampaikan kepada PT. Bisma Dharma Kencana, PT. Arjuna Utama Sawit, dan PT. Mitra Jaya Cemerlang yang telah membantu pendanaan selama kegiatan.

\section{DAFTAR PUSTAKA}

Aziz, A. 2000. Upaya menghimpun dan melestarikan darah. Bulletin transfusi darah. Vol: 27 (279). 
Budiningsih, A. 2011. Gambaran faktor-faktor yang mempengaruhi motivasi pendonor sukarela untuk mendonorkan darah di UTD-PMI Kota Medan tahun 2010. [Skripsi]. FKM USU, Medan. Tidak dipublikasikan.

Departemen Kesehatan Republik Indonesia (Depkes RI). 2009. Donor darah, hidup sehat sambil beramal. www.health.detik.com. Diakses pada tanggal 31 Maret 2010.

Irianto, K. 2004. Struktur dan fungsi tubuh manusia untuk paramedis. Yrama Widya, Bandung.

Janice. 2009. Hubungan antara pengetahuan dan sikap tentang donor darah dengan tindakan berdonor darah pada mahasiswa Fakultas Kedokteran Universitas Sumatera Utara. [Skripsi]. FKM USU, Medan. Tidak dipublikasikan.

Masser BM, White, KM, Hyde MK, Terry DJ. 2008. The psychology of blood donation: current research and future direction. Transfusion Medicine Rev 22 (3): 215-233.

Notoatmodjo S. 2007. Ilmu kesehatan masyarakat. Rineka Cipa, Jakarta.
Palang Merah Indonesia (PMI). 2002. Serba-serbi transfusi darah. www.palangmerah.org/pelayanan transfusi.asp. Diakses pada 25 Februari 2009.

Sari, LP. 2012. Faktor-faktor yang mempengaruhi pendonor darah sukarela pada masyarakat pribumi dan nonpribumi di Unit Transfusi Darah Palang Merah Indonesia Kota Medan. [Tesis]. FKM USU, Medan. Tidak dipublikasikan.

Syaifuddin. 1995. Anatomi fisiologi untuk perawat. Edisi 10. EGC, Jakarta.

Unit Transfusi Darah-Palang Merah Indonesia (UTD-PMI). 2010. Donor darah. UTD-PMI, Medan.

Windarto, LB. 2011. Kegiatan komunikasi dan partisipasi darah sukarela: Studi korelasi hubungan antara aktivitas mahasiswa dalam mengikuti kegiatan komunikasi pencari pelestari donor darah sukarela (P2D2S) PMI Cabang Kota Surakarta dengan partisipasi mahasiswa Fisip UNS sebagai pendonor darah sukarela. [Skripsi]. Fisip UNS, Surakarta. Tidak dipublikasikan. 